\section{Generational differences in work in Spain. A review}

\author{
Jose Manuel Lasierra ${ }^{1}$ \\ ${ }^{1}$ University of Zaragoza, Faculty of Social \\ Sciences and Labor, Applied Economics
}

\begin{abstract}
Purpose - The objective of this paper is to analyze the existence of generational differences in work in a series of variables that affect job satisfaction, distinguishing workers born before the 70s, known as Boomers, and those born after that date, Generation X.
\end{abstract}

Design/methodology/approach - Methodologically an earlier analysis is extended with the application of a Univariate General Linear Model that allows measuring the differences of a collective with respect to the base group. The work expands the explanatory capacity of a previous work in which linear regressions was applied to each of the two groups, Boomers and Generation X.

Findings - The results highlight these differences in which a group of workers appears with a more traditional profile that responds to the profile of the Fordist worker and a generation of younger workers less committed to the company, less identified with the work. For these workers, work is just a way of life, from which they do not obtain any immaterial value.

Originality/value - This paper concludes by considering the implications the findings have for work management both in theory and in practice. According to these differentiated profiles, management and incentive policies in the company should take into account these differences when recruiting, retaining and managing human resources.

Keywords - Generational groups, work organization, job satisfaction,
Received on

$01 / 30 / 2018$

Approved on

03/7/2019

Responsible editor:

Prof. Dr. Gina Gaio Santos

Evaluation process:

Double Blind Review

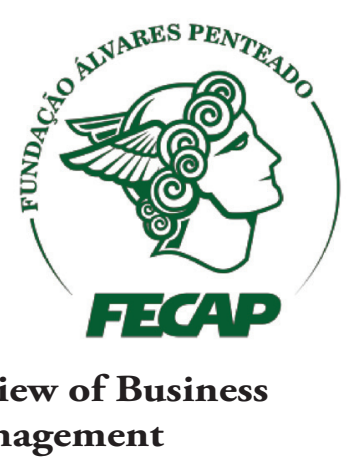

DOI: $10.7819 /$ rbgn.v21i5.4024 
human resources

\section{Introduction}

The existence of different groups of workers in a company can present certain problems in human resource management if the characteristics of these groups are not taken into account. Although the company can be considered a homogeneous unit - as in the neoclassical theory of the company - applying uniform management systems to different collectives can cause inefficiencies in the company and have a negative impact on results. Treating all employees equally can reduce the distributive conflict, which is an important issue, as Robert Solow (1992) reminds us. However, addressing different perceptions of work and the most common values can maintain efficiency in management without worsening the distributive conflict. In a study of organizations with 500 employees or more, Burke (2005) pointed out that $58 \%$ of managers reported conflicts between younger and older workers.

Our basic hypothesis is that there are, in fact, groups differentiated by age; that is to say, different generations with different perceptions of the world of work, both in what they expect from work and what they can bring to it, which will affect their behavior at work. The objective of this research is to verify the existence of these generations and the characteristics they show in relation to their work. Age has always been an important variable in studies of human resources and job satisfaction, but we believe that it is possible to talk about age brackets that indicate clearly differentiated groups, collectives that correspond to generations and that can demand particular labor policies and specific approaches to human resources.

Generational change has been an important issue in economic, social, and political analysis. In the world of work, technical and economic transformations no longer guarantee the characteristics present in the era of the Fordist worker, such as "employment for life". On the contrary, what such transformations show is a worsening of wage and employment conditions, indicating that current, younger generations will not attain the levels enjoyed by their parents, a phenomenon that is observed in many countries, and that technical changes now happen much faster and knowledge becomes obsolete much more quickly, which introduces significant difficulties in the durability of work and permanence of employment. However, it is not only different labor realities that mark these differences; there are also changes in values and motivations. We will analyze the different generations based on the influence that individuals in the sample show on Job Satisfaction (JS). For the Spanish case, we find an abundant literature about JS. Gamero (2004, 2005, 2007 , 2010) analyzes the JS of wage-earners according to gender, type of contract, and nationality. Rico (2012) differentiates by gender, points out the marginal differences, and distinguishes between natives and immigrants. However, within the different groupings of the labor market, we do not find studies for Spain that differentiate between generations, a reality that is fully observable, and that we believe is important in understanding the functioning of the labor market.

The contributions of this research are several. We begin with a very broad informative source (treated in a previous study, published as a Working Paper, by Lasierra et al., 2015) that helps us to better define the most important variables and analyze their effects. Methodologically, we apply the Univariate General Linear Model (GLM) with Interactions, a statistical technique that complements other research, such as logit analysis, probit, specific regressions for each group (as in our Working Paper), and multiple choice models, such as in Rico (2012). The GLM allows us to analyze the changes from one generation to the next in the workplace. We believe that the application of GLM confronts one of the problems that Lyons and Kuron (2014) point to, regarding certain shortcomings in terms of rigor, due to methodological and information issues, in a subject that has accumulated substantial literature for almost two decades. To the best of our knowledge, there are no scientific works on the generational problem for the Spanish 
case. However, the subject has attracted much journalism and analysis, and aroused the interest of managers, who face the day-to-day management of human resources in organizations and companies (Burke, 2005).

Our study confirms generational differences as a variable to be taken into account in the management of human resources, in the configuration of the labor market, and in labor policies. The results can be useful for human resource managers and also for public policies designed to promote a more or less regulated labor market, accompanied by more or less intervention in the market.

We first present an introduction to the problem, describing the objective of the paper, the motivation behind it, and an indication of its value and its contributions. In the second section, we refer to the recent social and political past to frame the study. In the third section, we proceed to a review of the literature related to our hypothesis. We then describe and present the explanatory model, along with the results and our analysis of them. From this analysis, we extract consequences for personnel management policies, and public policies for the labor market. Finally, we summarize the study, pointing out its limitations and briefly outlining possible extensions of the work.

\section{Socioeconomic background of the Spanish labor market}

In the socio-economic history of Spain of the last 50 years, different realities are observed between two generations that have configured different attitudes to work and to labor relations. First, the generational periods should be delimited. In European and American studies, the Baby Boom generation begins at the end of the 1940s. In the Spanish case, the demographic explosion is a bit later, as we have indicated previously.

Delimiting the dividing line, we note that the Spain of the 1950s began to emerge from the harsh period of autarky (it was not until 1953 that Spain's GDP got back to the level of 1935). Spain was an agrarian and rural country that then began to industrialize and urbanize. In the 1960 s, $38 \%$ of the active population worked in agriculture. By the mid-1980s, this number was down to $18 \%$. There was a significant exodus from the countryside to the cities. The nascent industrial sector had a low level of development, serving the domestic market and depending on foreign investment for its growth and modernization. In the sociological field, traditional customs, conditioned by the Catholic Church, were dominant, and class differences were clearly defined, with a low cultural level and minimal training. In the political realm, dictatorship and unions upheld job stability in employment, in exchange for the suppression of freedom of association. In short, there was a high level of backwardness in all economic, political, and social aspects, compared to other European countries.

Those born in the 1970s, when they joined the world of work, from the late 1980s, found a country of services, open to a world of modern customs and social and personal relationships, and with an income level that had grown significantly in comparative terms with Europe. In 1986, Spain joined the European Union, in a context of freedom and modernity. These socio-economic conditions mark different generational behaviors in the world of work, between the Boomers, aged between 43 and 65 years old, and the Gen-Xers, aged from 25 to 42 years old. The Gen-Xers enjoyed a period of intense economic growth and only when they began to reach biological maturity, when the Millennials came on the scene, did the phenomenon of "precariado" (Standing, 2013) begin to appear.

But the generations are not distinguished only by birth. As Cogin (2011) notes, multigenerational theory holds that it is not just a question of age. There are factors - life experiences, cultures, perceptions of society, politics, family, life in general - that mark generational differences. This is what we believe is happening at the moment and is the focus of our interest: there are two groups in the same workplace that have had different life experiences and have different visions of society, the economy, and politics. The pertinent question is: should we treat the workers of a company as a homogeneous collective, or should we, for the sake of better management, 
point out the possible (certain in our opinion) existing generational differences and take them into account?

We base our work on a large sample of individuals and a large number of variables, provided by the Survey of Quality of Life at Work (ECVT) from 2006 to 2010, prepared by the Ministry of Labor and Social Affairs (the methodology and variables of the survey, with values, can be found on the Ministry's website: http://www.empleo.gob.es/estadisticas/ecvt/ ecvt2010/). This is a survey of about 7,000 individuals per year, which is cross-sectional in nature. We incorporate all 5 years to obtain the classification of the two generations under study: the Boomers and the Gen-Xers. The references that we analyzed in the literature use much smaller samples and, preferably, focus on public sector workers. This survey has not been prepared since 2010. We must bear in mind that the range of years includes a period of intense economic growth until 2007-2008, followed by rapid growth in unemployment, which did not peak until 2014, five years later. In some quarters, during that time, unemployment exceeded 26\% of the active population, and was particularly heavy amongst the young (more than 50\% unemployment rate) and in particular among those under 30 years of age. This experience may well have influenced the perceptions of the GenXers of the world of work and regarding their job satisfaction and job security. However, we believe that our results are validated, because the age brackets of the selected generations are broad. The Gen-Xers, for example, range from 25 to 42 years old, an age that can hardly be considered young for an employee.

\section{Review of the literature and working hypothesis}

The first question in the literature on the generational issue refers to the very existence and delimitation of two or more possible generations. Various authors point to the existence of such differences. From sociology, McMullin et al. (2007) state that individual attitudes and values are the result of the economic, social, and political situations that those involved have experienced. Schuman \& Scott (1989) point out that these generational differences can be observed from the selective memory of certain events that results in individual attitudes and different collective values.

These generational differences are observed in a wide variety of social aspects, such as family structure (Gans \& Silverstein, 2006; Alwin, 1990); social movements (Alwin \& Krosnick, 1991); and cultural changes, such as the assumption of Western values in Asian countries (Hui-Chun \& Miller, 2005). Even biographical transformations are signaled as the breaking of Maslow's hierarchy of vital needs, so that the Gen-Xers compress and unify some of the phases that the Boomers clearly differentiated (Shu, 1998).

In the economic field, important differences in consumption and marketing can be observed, in Yankelovich (2000) and Roberts \& Manolis (2000).

In the labor field, the focus of this work, opinions on the existence of differences are not unanimous. For example, in a study of public employees related to motivating factors at work, Jurkievicz (2000) observes more similarities than differences between the generations, but also finds some significant differences. On the other hand, Wallace (2006) observes some differences, but which are not of great significance, while Giancola (2006) refers to these differences being more a myth than a reality.

Other authors consider that generational differences at work are a reality. Smola \& Sutton (2002) point out that the values of work are more influenced by generational experience than by age and maturity. For example, they find that as individuals age, work is less idealized, while Generation X, paradoxically, approaches the working world with a less idealized perspective; they do not contemplate employment for life in the same company. Similarly, the Gen-Xers have not had the opportunity to become "disenchanted", so their attitudes must be a consequence of a working reality that is different from that of the Boomers. Appelbaum et al. (2005) find that the Gen-Xers are less satisfied at work and identify less with the company than the Boomers do. Daboval (1998) obtains the same result, while Benson \& Brown (2011) observe few generational differences in 
the level of commitment or identification, but do identify a higher level of job satisfaction among the Boomers.

All this leads us to our first hypothesis:

H1: Gen-Xer workers are less committed to the company.

To evaluate this hypothesis, the variables used have to do with knowledge of the objectives of the company, with satisfaction with the activity developed, and with satisfaction with the degree of job stability.

In terms of values and commitment to work, the Gen-Xers, according to Jorgensen (2003), value more autonomy and independence. Boomers believe in employment for life and have a certain idea of commitment and collective spirit. On the contrary, Gen-Xers value loyalty less; perhaps because the daily reality does not offer them much security or job stability, they think more about themselves and look for a basic balance between work and personal life. These ideas are also supported by Smola \& Sutton (2002) and Hui \& Miller (2005). Arsenault (2004) discerns more honesty in the Boomers than in the GenXers, who have more determination and ambition in regard to work performance.

We consider, however, that hard work and enjoyment of leisure are two variables that, in principle, seem to differentiate the generations. The Gen-Xers seek, from the beginning of their working lives, a balance between work and leisure. It could be said that they "have a life" outside of work. For the Boomers, in general, work plays a central role in their life and so, when they retire, many Boomers are displaced from society and develop a sense of "uselessness". Brown (2012) summed this up in the idea that Boomers "live to work" and Gen-Xers" work to live".

In terms of leadership styles, Hui \& Miller (2005) make an interesting contribution that comes close to our initial reflections, illustrating the logic of the productive system, according to which the productive structure conditions the systems of organization. In the opinion of these authors, Boomers and Gen-Xers adopt the forms of leadership that correspond to Theory $\mathrm{X}$ and
Theory Y of organizations, respectively.

In summary, the leadership and management of work under Theory X correspond to the industrial economy: a productive system of rather large companies, in which technical change takes time and in which the management of work demands supervision and control. Theory Y, on the other hand, is applied to the service economy, in which interpersonal communication, customer service, and conflict resolution will prevail.

According to this classification, which relates productive systems to management models, Boomers have values at work that are characterized by commitment to the job and to the employer, and by fidelity and obedience, all in an attitude of respect for authority and loyalty. To those values and attitudes, the company responds with recognition, security, and protection. For their part, Gen-Xers have values that are more linked to individualism. They seek personal satisfaction and adopt an individualization of work instead of a collective vision (Sirias et al., 2007). The hypothesis to verify this would be:

H2: Gen-Xer workers are less committed to work.

The variables that measure this are the degree of satisfaction with autonomy and independence, satisfaction with the day, and with the activity developed. Job stability induces Gen-Xers to feel more committed to their jobs. With this last variable, we attempt to capture the differences in JS derived from contractual modalities that do not fit fixed and full-time employment.

As for the gender variable, we think that there has been a clear generational shift in terms of a greater presence of women in the workplace (Benson \& Brown, 2011; Eckman, 2004). Studies show a greater level of JS among women than men (Lydon \& Chevalier, 2002; Sloane \& Williams, 2000 ), and in our case, given the delay in women entering the job market in Spain, their presence among the Gen-Xers is greater than among the Boomers.

On the other hand, Hui and Miller (2005) emphasize that the Gen-Xers care more about the 
profession itself than the particular company; rather than getting promoted within the company, they prefer to take advantage of the opportunities to train. Their attitudes are based on a search for quality of life, continuous learning, and improvement of their abilities. What they expect from the company is that it offers challenges and rewards, recognizes their contribution, and provides freedom to develop initiatives.

\section{H3: Training is more important for the Gen-Xers than for the Boomers.}

The variables that incorporate the aspects related to this hypothesis are related to training, occupation, and studies.

In terms of salary and remuneration, both groups should value pay as a determinant of job satisfaction (Sloane \& Williams, 2000; Clark \& Oswald, 1996; Groot \& Massen, 1999), particularly relative income. However, given the attitudes and preferences of the Gen-Xers for leisure and life "outside" the company, their economic needs may be greater than those of the Boomers, and so the influence of income on JS is greater among the Gen-Xers than the Boomers.

\section{H4: Salary level is more important for the} Gen-Xers than for the Boomers.

The Income variable is used to verify this hypothesis.

The Boomers, who were born in the industrial economy, have had to adapt to the service economy, and to the new knowledge economy. The Gen-Xers have no experience of the industrial economy. Management styles have been adapted to the different aspirations of different generations, but Hui \& Miller (2005) point out that labor characteristics (values, attitudes, and expectations) also depend on the sector and on the occupation, as well as on a specific generation. Analyzing the education sector and a branch of the industrial sector, they observe that in the education sector important generational differences are not obvious, while in the industrial sector differences clearly appear. Their conclusion is that the sector makes much of the labor characteristics of the worker. Our understanding of the work of Hui and Miller (2005) is that it is not so much the specific occupation, but the sector that makes for labor differences. This brings us to the notion that management styles should consider both the productive structure and the sector in which the company operates, along with the generational difference. Benson \& Brown (2011) observe that JS is closely tied to the level of co-worker support existing in the workplace.

In Lasierra (2012), we also see the importance of factors related to labor and personal relations at work in JS. Regarding the size of the company, which is recognized as having an influence on Job Satisfaction (see Lydon \& Chevalier, 2002), we cannot establish any hypothesis a priori. However, the larger size of the industrial companies offered greater possibilities for social relationships within the company, so that the Boomers found greater JS than the GenXers do in the companies of the service economy.

H5: The Boomers value a friendly work and social environment in the workplace more highly than the Gen-Xers do.

The variable that will ascertain the value of this hypothesis is a factor (Good labor and social relations), extracted by principal components, of 4 questions related to the subject's satisfaction with their relationships with colleagues and with management, and their confidence in both managers and colleagues.

Finally, the general hypothesis is that the Gen-Xers are individuals who consider work as a means to earn a living, without showing excessive loyalty to the company. The consequence would be that the JS of the Boomers is greater than that of the Gen-Xers. Consequently, our final hypothesis is:

H6: Boomers' job satisfaction is greater than that of Gen-Xers.

Our study hypotheses are based on the notion that the characteristics and circumstances of the socio-economic environment in which the 
individual develops configure their conception of life and condition their behavior at work. Therefore, our general hypothesis is that there really are differences between the two generations that we consider.

These differences are manifested in the perception that the individuals have, first of all, regarding JS. Second, generational differences also appear in relation to different aspects of labor relations and working conditions, and in some variables of a personal nature that influence the level of motivation or identification of the worker with the company. From the literature cited, we extract the variables of the model summarized in Table 1. The last column shows which has the

highest value, Boomers or Gen-Xers, or whether they are equal, according to the assumptions from the literature.

Table 1

\section{Descriptive statistics}

\begin{tabular}{|c|c|c|c|c|c|}
\hline Descriptive and influence hypothesis & & $\mathrm{N}$ & Mean & $\begin{array}{l}\text { Stand } \\
\text { Dev }\end{array}$ & $\begin{array}{l}\text { Influence of the variables on JS according } \\
\text { to the literature that bases the hypotheses: } \\
\text { Boomers \& Xers }\end{array}$ \\
\hline \multirow[t]{2}{*}{ Gender: Male $=58 \%$; Female $=42 \%$} & Xers & 15784 & 1.46 & 0.50 & $\begin{array}{l}\text { Xers > Boomers (Benson \& Brown, 2011; } \\
\text { Eckman, 2004; Lydon \& Chevalier, 2002; } \\
\text { Clark, 1997) }\end{array}$ \\
\hline & Boomers & 13599 & 1.42 & 0.49 & \\
\hline \multirow{2}{*}{ Level of studies: $1=$ Illiterate; $10=\mathrm{PhD}$} & Xers & 15784 & 6.03 & 2.07 & $\begin{array}{l}\text { Xers > Boomers (Benson \& Brown, 2011; } \\
\text { Iverson \& Buttigieg, 1999; Camilleri, 2002) }\end{array}$ \\
\hline & Boomers & 13599 & 5.51 & 2.26 & \\
\hline \multirow{2}{*}{ Job Satisfaction : $0=$ None; $10=A$ lot } & Xers & 15784 & 7.22 & 1.76 & Most widespread hypothesis: Boomers $>$ Xers \\
\hline & Boomers & 13599 & 7.32 & 1.81 & \\
\hline \multirow{2}{*}{$\begin{array}{l}\text { Knowledge of company objectives: } \\
0=\text { None; } 10=\text { A lot }\end{array}$} & Xers & 15784 & 7.11 & 2.73 & Boomers > Xers (Appelbaum et al., 2005) \\
\hline & Boomers & 13599 & 7.07 & 2.87 & \\
\hline \multirow{2}{*}{$\begin{array}{l}\text { Satisfaction with the activity developed: } \\
0=\text { None; } 10=\text { A lot }\end{array}$} & Xers & 15784 & 7.60 & 1.81 & Boomers > Xers (Appelbaum et al., 2005) \\
\hline & Boomers & 13599 & 7.71 & 1.79 & \\
\hline \multirow{2}{*}{$\begin{array}{l}\text { Satisfaction with autonomy and } \\
\text { independence: } 0=\text { None; } 10=\mathrm{A} \text { lot }\end{array}$} & Xers & 15784 & 7.16 & 2.27 & Xers > Boomers (Jurkiewicz, 2000) \\
\hline & Boomers & 13599 & 7.31 & 2.25 & \\
\hline \multirow{2}{*}{$\begin{array}{l}\text { Satisfaction with the working day: } 0= \\
\text { None: } 10=\text { A lot }\end{array}$} & Xers & 15784 & 7.01 & 2.29 & Xers > Boomers (Smola \& Sutton, 2002) \\
\hline & Boomers & 13599 & 7.25 & 2.17 & \\
\hline \multirow{2}{*}{$\begin{array}{l}\text { Satisfaction with stability: } 0=\text { None; } 10= \\
\text { A lot }\end{array}$} & Xers & 15784 & 7.16 & 2.63 & Boomers > Xers (Meyer \&Allen, 1997) \\
\hline & Boomers & 13599 & 7.70 & 2.41 & \\
\hline \multirow{2}{*}{$\begin{array}{l}\text { Adequacy of the training received in the } \\
\text { position: } 1=\text { Very suitable ; } 4=\text { Not at all } \\
\text { suitable }\end{array}$} & Xers & 15784 & 1.34 & 0.65 & $\begin{array}{l}\text { Xers > Boomers } \\
(\text { Sirias et al., 2007) }\end{array}$ \\
\hline & Boomers & 13599 & 1.24 & 0.56 & \\
\hline \multirow{2}{*}{$\begin{array}{l}\text { Net monthly income } \\
\text { (From } 1 \text { to } 9 \text { ) }\end{array}$} & Xers & 15784 & 3.16 & 1.33 & $\begin{array}{l}\text { Boomers = Xers ( Morris et al., 1993; Clark \& } \\
\text { Oswald, 1996) }\end{array}$ \\
\hline & Boomers & 13599 & 3.49 & 1.51 & \\
\hline \multirow{2}{*}{$\begin{array}{l}\text { Occupation : } 1=\text { Senior manager; } 5=\text { non- } \\
\text { qualified staff }\end{array}$} & Xers & 15728 & 3.61 & 1.08 & $\begin{array}{l}\text { Boomers > Xers } \\
\text { (Rose, 2003; Smith, 2007) }\end{array}$ \\
\hline & Boomers & 13553 & 3.62 & 1.13 & \\
\hline
\end{tabular}




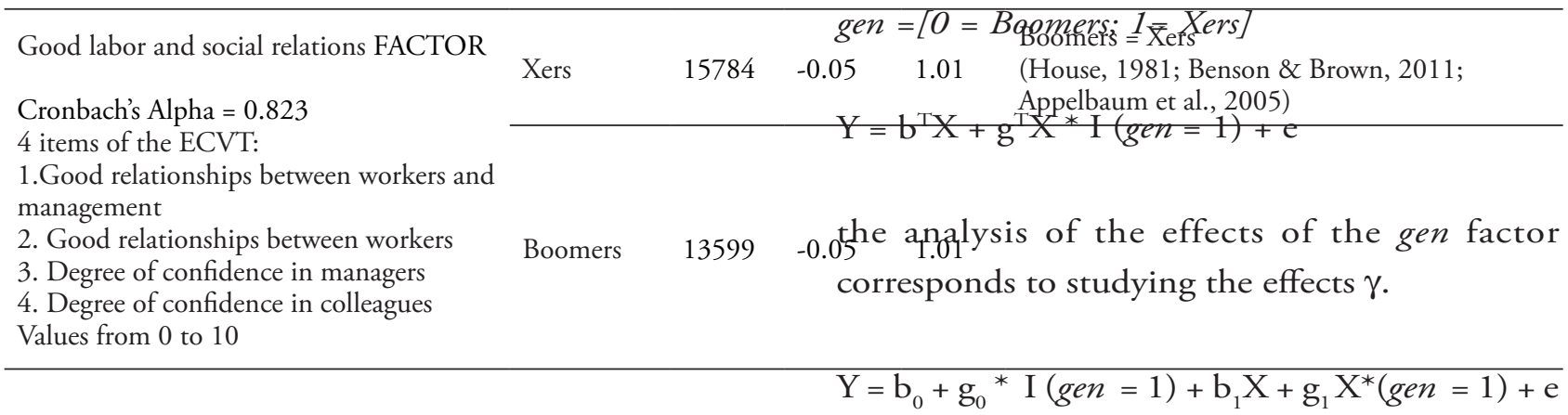

\section{Explanatory model}

In our analysis, we consider only one dependent variable, Job Satisfaction, to answer a question about the degree of job satisfaction felt by the interviewee, scoring from 0 to 10 . Regarding the independent variables, we extract the least important variables, with respect to the initial Working Paper (which had 24 variables), to eliminate "noise", and retain the ones that really mark the generational differences. Later, in a second stage (Table 3), we run another regression by eliminating the only variable that remains as non-significant (Occupation) and also the Interactions that were not significant. Significant Interactions are those that reflect a difference between the generations. In addition, some categorical variables, such as Occupation, Level of studies, and Gender, have been taken as continuous numerical variables. We try to discern the influence in general, rather than looking for precision, regarding how the Boomers or the Gen-Xers feel, depending on their particular professions.

The theoretical model is based on the establishment of a statistical hypothesis that the two generations are different. We apply the Univariate General Linear Model (GLM) in the following way:

$\mathrm{y}=\mathrm{bX}+\mathrm{e}$

with generational factor interaction (1: Baby Boomers generation, aged 43 to 65 years old, and 0: Generation Xers, from 25 to 42 years old):
With the significant effects of gen $\left(\gamma_{0} \neq\right.$ $0)$ and the interaction of gen and independent variables $X\left(\gamma_{1} \neq 0\right)$, the equations of the model would be:

$\mathrm{Y}=\mathrm{b}_{0}+\mathrm{b}_{1} \mathrm{X}+\mathrm{e}$ for Boomers and

$\mathrm{Y}=\mathrm{b}_{0}+\mathrm{g}_{0}+\left(\mathrm{b}_{1}+\mathrm{g}_{1} \mathrm{X}+\mathrm{e}\right.$ for Generation Xers.

The analysis of differences is incorporated in this model, in which the hypothesis $\mathrm{H}_{0}$ is: $\bigotimes_{1}$ $=0$ expresses differences in average level between Boomers and Gen-Xers.

Regarding the application of the statistical model, we note that: 1) Given the large amount of data, the statistical techniques are robust and the results do not indicate heteroscedasticity problems. 2) We also observe no problems of collinearity. Applying the variance inflation factor yields results below 10, thus indicating no problem (Lin et al., 2011). 3) In relation to the possible problem of endogeneity, we understand that the database itself, the ECVT, is prepared to highlight the value of the dependent variable JS, which is to be explained with a high number of specific questions as covariables.

The GLM with Interactions points to the significant variables and the values that a base group takes (in our case, the Boomers) so that from this base group we can consider how the workers of Generation X differ compared with the base generation. Reducing the number of variables to really significant ones, compared to the initial Working Paper (Lasierra et al., 2015), allows us 
to indicate the characteristics of the Boomers and to establish what has changed in the subsequent generation. Reducing the variables between the previous study and the statistical model applied allows for more precision in the results.

\section{Results}

The selected variables, from the first approach mentioned, capture personal characteristics of the individuals, gender, level of studies, occupation, and labor aspects related to salaries, working hours, stability, training in relation to the position held, satisfaction with the activity developed, knowledge of the company, and labor and social relations within the company.

In the GLM, with all the variables and their Interactions (Table 2), the base group is Boomers. All independent variables appear as significant, except Occupation with an $\mathrm{R}^{2}=$ $55 \%$. Four interactions indicate generational differences: "Level of studies", "Knowledge of the objectives of the company", "Satisfaction with the

activity developed", and "Net monthly income". In this model, the variable that produces the most job satisfaction in the Boomers is "Good social and labor relations in the company", followed by "Satisfaction with the working day" and "Satisfaction with the activity developed". The "Occupation" variable does not appear as significant. In this regression, we find 6 Interactions that show no change in the behavior of the Gen-Xers with respect to the Boomers.

Table 2

\section{Estimation of the Job Satisfaction model}

\begin{tabular}{|c|c|c|c|}
\hline Dependent Variable: & $\mathbf{R}$ & t & Siq \\
\hline Job Satisfaction & $\mathbf{D}$ & $\mathbf{l}$ & Jig. \\
\hline 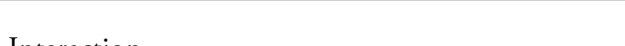 & 1.84 & 16.90 & 0.00 \\
\hline m & $(0.11)$ & & \\
\hline LOPDF $1001 C_{0}$ Y & 0.42 & 2.81 & 0.01 \\
\hline 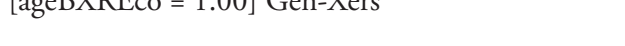 & $(0.15)$ & & \\
\hline$[$ ageBXREco $=0.00]$ Boomers & $0^{\mathrm{a}}$ & & \\
\hline Cender $\mathrm{r}$ & 0.04 & 1.70 & 0.09 \\
\hline Gender & $(0.02)$ & & \\
\hline Ionelof ctudie & -0.03 & -4.50 & 0.00 \\
\hline Lever or stucies a & $(0.01)$ & & \\
\hline 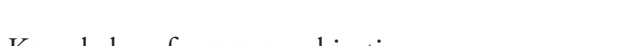 & 0.03 & 6.13 & 0.00 \\
\hline 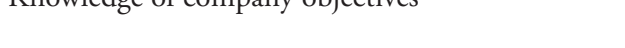 & $(0.00)$ & & \\
\hline 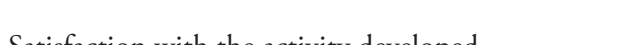 & 0.36 & 49.84 & 0.00 \\
\hline Satiolaction & $(0.01)$ & & \\
\hline & 0.12 & 20.82 & 0.00 \\
\hline satistaction witn the autonomy and independence & $(0.01)$ & & \\
\hline 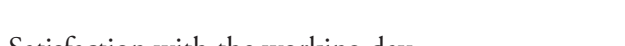 & 0.15 & 27.68 & 0.00 \\
\hline 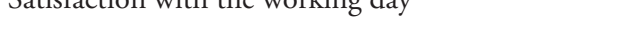 & $(0.01)$ & & \\
\hline Saticfoction with the ctobilitwe & 0.09 & 17.32 & 0.00 \\
\hline Satistaction witn the stadimty & $(0.01)$ & & \\
\hline Dependent Variable: & $\mathbf{R}$ & a & $\mathbf{c} \cdot \mathbf{p}+\mathrm{C}$ \\
\hline Job Satisfaction & $\mathbf{D}$ & $\mathbf{t}$ & Jig. \\
\hline degrom of the training received in the nocition & -0.12 & -6.32 & 0.00 \\
\hline 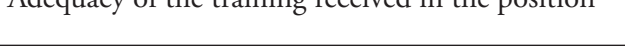 & $(0.02)$ & & \\
\hline
\end{tabular}




\begin{tabular}{|c|c|c|c|}
\hline \multirow{2}{*}{ Net monthly income } & 0.05 & 5.28 & 0.00 \\
\hline & $(0.01)$ & & \\
\hline \multirow{2}{*}{ Occupation } & 0.01 & 0.71 & 0.48 \\
\hline & $(0.01)$ & & \\
\hline \multirow{2}{*}{ Good labor and social relations Cronbach's alpha $=0.823$} & 0.33 & 26.68 & 0.00 \\
\hline & $(0.01)$ & & \\
\hline \multirow{2}{*}[\text{ageBXREco}=1.00]{$*$ Gender } & 0.01 & 0.40 & 0.69 \\
\hline & $(0.03)$ & & \\
\hline \multirow[b]{2}{*}[\text{ageBXREco}=1.00]{$^{*}$ Level of studies } & 0.02 & 2.31 & 0.02 \\
\hline & $(0.01)$ & & \\
\hline \multirow{2}{*}[\text{ageBXREco}=1.00]{$*$ Knowledge of company objectives } & -0.01 & -2.04 & 0.04 \\
\hline & $(0.01)$ & & \\
\hline \multirow{2}{*}[\text{ageBXREco}=1.00]{$*$ Satisfaction with the activity developed } & -0.05 & -5.43 & 0.00 \\
\hline & $(0.01)$ & & \\
\hline \multirow{2}{*}[\text{ageBXREco}=1.00]{$*$ Satisfaction with the autonomy and independence } & 0.00 & -0.20 & 0.84 \\
\hline & $(0.01)$ & & \\
\hline \multirow{2}{*}[\text{ageBXREco}=1.00]{$*$ Satisfaction with the working day } & 0.00 & 0.38 & 0.71 \\
\hline & $(0.01)$ & & \\
\hline \multirow{2}{*}[\text{ageBXREco}=1.00]{$*$ Satisfaction with the stability } & 0.00 & -0.08 & 0.94 \\
\hline & $(0.01)$ & & \\
\hline \multirow{2}{*}[\text{ageBXREco}=1.00]{$^{*}$ Adequacy of the training received in the position } & -0.02 & -0.76 & 0.45 \\
\hline & $(0.03)$ & & \\
\hline \multirow{2}{*}[\text{ageBXREco}=1.00]{$*$ Net monthly income } & 0.02 & 1.61 & 0.11 \\
\hline & $(0.01)$ & & \\
\hline 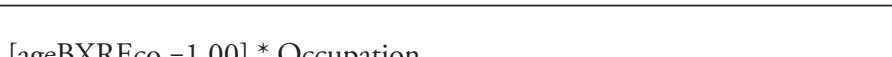 & -0.01 & -0.51 & 0.61 \\
\hline
\end{tabular}

$[\text { ageBXREco }=1.00]^{*}$ Occupation $\quad$ also has a negative $\beta_{0}^{-0}$ the greater the inadequacy,
the lower the satisfaction. All the variables appear $[$ ageBXREco $=1.00] *$ Good labor and social relations Cronbach's alpha $=2_{s} 833$ gnificant. By $y_{02}$ xcluding non-significant

(Standard error in brackets)

When we refine the non-significant variable, Occupation, and the interactions that do not show generational differences, in Table 3, the variables that contribute most to the JS of the Boomers are: "Satisfaction with the activity developed", "Satisfaction with the working day", "Satisfaction with the autonomy and independence", and "Satisfaction with the stability". "Level of studies" has a negative $\beta$ : the higher the level of studies, the less job satisfaction. "Adequacy of the training received in the position" interactions from the regression, we retain 5 that are significant, which indicate the differences between the generations.

The meaning of these Interactions, according to the explanatory model, is:

- Knowledge of the objectives of the company produces more satisfaction in the Boomers than in the Gen-Xers $\left(\mathrm{H}_{1}\right)$.

- Satisfaction with the activity carried out is also greater in the Boomers than in the Gen-Xers $\left(\mathrm{H}_{2}\right)$.

- A higher level of studies (negative $\beta$ ) produces less job satisfaction in the Boomers than in the Gen-Xers $\left(\mathrm{H}_{3}\right)$. 
- A higher salary level produces more job satisfaction in the Gen-Xers than in the Boomers $\left(\mathrm{H}_{4}\right)$.

- Good labor and social relations produce more satisfaction in the Gen-Xers than in the Boomers $\left(\mathrm{H}_{5}\right)$.

Table 3

\section{Final model estimated for Job Satisfaction}

\begin{tabular}{|c|c|c|c|c|c|c|c|c|c|}
\hline \multirow{2}{*}{ Job Satisfaction } & \multirow{2}{*}{$\beta$} & \multirow{2}{*}{$\mathbf{t}$} & \multirow{2}{*}{ Sig. } & \multicolumn{6}{|c|}{ Generation Xers } \\
\hline & & & & $\gamma$ & $\mathbf{t}$ & Sig. & $\beta$ & $\gamma$ & $\beta+\gamma$ \\
\hline Interaction & $\begin{array}{c}1.89 \\
(-0.07) \\
\end{array}$ & 28.37 & 0.00 & $\begin{array}{c}0.36 \\
(0.08)\end{array}$ & 4.49 & 0.00 & 1.89 & 0.36 & 2.25 \\
\hline Gender & $\begin{array}{c}0.04 \\
(0.02) \\
\end{array}$ & 2.87 & 0.00 & $\begin{array}{c}0.01 \\
(0.03)\end{array}$ & 0.42 & 0.67 & 0.04 & 0.04 & 0.05 \\
\hline Level of studies & $\begin{array}{l}-0.03 \\
(0.01)\end{array}$ & -5.76 & 0.00 & $\begin{array}{c}0.02 \\
(0.01)\end{array}$ & 3.12 & 0.00 & -0.03 & 0.02 & -0.01 \\
\hline Knowledge of company objectives & $\begin{array}{c}0.03 \\
(0.00) \\
\end{array}$ & 6.13 & 0.00 & $\begin{array}{l}-0.01 \\
(0.01)\end{array}$ & -1.98 & 0.05 & 0.03 & -0.01 & 0.02 \\
\hline Satisfaction with the activity developed & $\begin{array}{c}0.36 \\
(0.01)\end{array}$ & 52.49 & 0.00 & $\begin{array}{l}-0.05 \\
(0.01)\end{array}$ & -5.92 & 0.00 & 0.36 & -0.05 & 0.31 \\
\hline $\begin{array}{l}\text { Satisfaction with the autonomy and } \\
\text { independence }\end{array}$ & $\begin{array}{l}0.12 \\
(0.0)\end{array}$ & 30.75 & 0.00 & $\begin{array}{c}0.00 \\
(0.01)\end{array}$ & -0.24 & 0.81 & 0.12 & 0.00 & 0.12 \\
\hline Satisfaction with the working day & $\begin{array}{l}0.15 \\
(0.0)\end{array}$ & 42.69 & 0.00 & $\begin{array}{c}0.00 \\
(0.01)\end{array}$ & 0.32 & 0.75 & 0.15 & 0.00 & 0.15 \\
\hline Satisfaction with the stability & $\begin{array}{l}0.09 \\
(0.0)\end{array}$ & 26.89 & 0.00 & $\begin{array}{c}0.00 \\
(0.01)\end{array}$ & -0.09 & 0.93 & 0.09 & 0.00 & 0.09 \\
\hline $\begin{array}{l}\text { Adequacy of the training received in the } \\
\text { position }\end{array}$ & $\begin{array}{l}-0.13 \\
(0.01)\end{array}$ & -10.98 & 0.00 & $\begin{array}{l}-0.02 \\
(0.02)\end{array}$ & -0.65 & 0.52 & -0.13 & -0.02 & -0.15 \\
\hline
\end{tabular}

\begin{tabular}{|c|c|c|c|c|}
\hline Net monthly income & $\begin{array}{c}0.05 \\
(0.01) \\
\end{array}$ & 5.59 & 0.00 & $\begin{array}{l}0.02 \beta=0.9225 ; \text { B } 0.05 \gamma=0.0 .5014 ; 0.02 a t \text { is } 6 \text {. ohis } \\
(0.01)_{\text {variable contributes } 60 \% \text { less to IS among }}\end{array}$ \\
\hline $\begin{array}{l}\text { Good labor and social relations } \\
\text { Cronbach's alpha }=0.823\end{array}$ & $\begin{array}{c}0.33 \\
(0.01)\end{array}$ & 27.36 & 0.00 & 0.03 the Gen-Xers than among the Boomers \\
\hline
\end{tabular}

(Standard error in brackets)

The value of the $\beta$ and $\gamma$ parameters of the Interactions (Table 3) allows us to quantify the generational differences that we have just indicated:

- The Interactions maintain the same final sign as the base variables, i.e. those of the Boomers; what varies is the incidence of Job Satisfaction.

- $\quad$ "Level of studies": $\beta=-0.032 ; \beta+\gamma=$ -0.009; that is, for the Boomers more studies means less JS; for the Gen-Xers this variable remains negligible at -0.009 .

- "Knowledge of company objectives": is an important difference.

- By the same procedure, we observe that "Satisfaction with the activity developed" decreases the JS of the Gen-Xers by $80 \%$, "Net monthly income" increases the JS of the Gen-Xers by $50 \%$ with respect to the Boomers, and "Good labor and social relations" in the company increases JS by $10 \%$ among the Gen-Xers.

Finally, the results indicate that the job satisfaction of the Gen-Xers is greater than that of the Boomers, as shown in Table 4. The values of 
the 95\% intervals do not overlap and the t-test also points to those differences between the generations. The mean test for independent samples is also significant, a result that we did not expect according to $\mathrm{H}_{6}$.

Table 4

\section{Mean Job Satisfaction}

\begin{tabular}{|c|c|c|c|c|c|c|}
\hline \multirow{2}{*}{ Job Satisfaction } & \multirow{2}{*}{ Mean } & \multirow{2}{*}{$\begin{array}{l}\text { Standard } \\
\text { error }\end{array}$} & \multicolumn{2}{|c|}{$95 \%$ confidence interval } & \multicolumn{2}{|l|}{ t test } \\
\hline & & & Lower limit & Upper limit & t statistic & Sig \\
\hline
\end{tabular}

\begin{tabular}{lll}
\hline Gen-Xers & 7.302 & 0.010 \\
\hline Boomers & 7.219 & 0.011 \\
\hline Equal variances are not assumed & & \\
\hline
\end{tabular}

Table 4 incorporates the results of a comparison test of the mean value in both generations, whose level of significance is 0.032 .

\section{Interpretation of results}

The results of the refined model (without variables and non-significant interactions) collected in Table 3 validate hypothesis $\mathrm{H}_{1}$ that the Gen-Xers are less committed to the company, give less importance to knowing the objectives of the company, and feel less involved with it than the Boomers. $\mathrm{H}_{2}$ is also validated: the Gen-Xers do not feel as satisfied with the activity developed as much as the Boomers do, which gives the idea that the work itself is not a stimulus, as it is for the older workers. The Gen-Xers also give greater importance to the salary level $\left(\mathrm{H}_{4}\right)$ in its contribution to job satisfaction. We could say that younger individuals, according to the aforementioned literature, are quite materialistic.

As for training $\left(\mathrm{H}_{3}\right)$, we consider this to be very important for the Gen-Xers and that it is closely tied to the activity performed. Effectively, the hypothesis is fulfilled: it is among the Boomers where the highest level of training produces the lowest levels of job satisfaction, perhaps deriving from a factor related to over-qualification, with the Gen-Xers feeling that they do not occupy a position that measures up to their qualifications. One of the criticisms of the Spanish labor market is that there is a surplus of university students and a workforce that is over-qualified for the lab. $2{ }_{33}$ needs, suche $321^{\text {as }}$ specialists in trades and int.95mediate pł.2ffossions. This possible excess training, in relation to the work te te be performed, produces a situation of underemployment at work; that is to say, individuals who perform functions that are well below their qualifications. This mismatch results in a level of frustration in the worker and, consequently, lower performance. (Our results do not show over-qualification problems in the labor market, although the coefficient is very low.)

One central aim of this paper is not fulfilled, which is to determine whether work is an important part of workers' lives. Those who value the work itself, such as the Boomers, should express more JS, but this is not borne out by our results for $\mathrm{H}_{6}$, as deduced from Table 4. The same happens with $\mathrm{H}_{5}$ : for the Gen-Xers, a good work environment contributes more to their JS than it does for the Boomers. For the Boomers, the activity and the work produce more JS than they do for the Gen-Xers, but what happens in the company, paradoxically, influences them less in their JS. Of course, the Gen-Xers are more hedonistic in their way of life and attitudes to work, as some sociologists, such as Alonso (2007), have pointed out.

In summary, the activity they perform does not give them great satisfaction, unlike the certain sense of professionalism and work well done that Fordist workers show. As a result, salaries to enjoy life "outside" of work and the company, and a good working environment within, are the determinants of the JS of the Gen-Xers.

Furthermore, the company as an employer does not generate an interest in or identification with its future. It is possible to venture that the 
Gen-Xers have their life "outside" of the company, and work is simply a means to obtain economic resources, without any deeper commitment. This is what sociologists have pointed out as the crisis of labor citizenship, based on the fact that work, in addition to a way of life, socializes and allows the working citizen to find meaning in their work, in the value of their production, and a sense of pride in a job well done, which contributes to individual and social well-being. The new generations no longer see work in this multidimensional way, or as adding meaning to their lives (Alonso, 2007). However, paradoxically, our results show that the Gen-Xers have a higher level of JS than the Boomers do. The Boomers came to expect, from the company and the work, something that gave meaning to what they did, and commitment to the organization; now, in the transition phase from the industrial economy to the service economy, perhaps those factors are no longer found in the workplace.

In this sense, our results show coherence with what is observed in the world of work today, both in what happens inside the company and in labor regulations. Within the company, more and more flexible measures are applied, possibly risking the stability of the labor relationship, so that the company's commitment to its workers is increasingly reduced. Work is more and more like a commodity. Whether due to the forces of economic and technical change, changes in business mentality, or the weakening of workers' organizations, companies increasingly uses their capabilities to reorganize work without showing commitment to their employees. On the other hand, outside companies, labor deregulation is an increasingly widespread practice in many countries, which favors the application of the aforementioned practices within companies. Faced with these two forces that push to understand work as a commodity, the Gen-Xers respond with less commitment: they do not find as much satisfaction in what they do, and they care less about the company's objectives. This notion leads us to ask whether a work force with these characteristics is the most appropriate to survive in an increasingly competitive environment. Our opinion is that it is not. This suggests that policymakers (both micro, in the company, and macro, in labor and labor market regulatory policies) should bear in mind what kind of workforce is to be encouraged and promoted in the economy as a whole.

However, we must point out that authors such as Brown (2012), while finding generational differences, do not believe that they are so important as to demand differentiated human resources policies. Others, such as Cogin (2011), point out that values at work that affect productivity or highlight the value of intrinsic incentives, such as satisfaction with the activity developed, as opposed to extrinsic ones, such as salary, or the perception of careerism within the company, are aspects that affect the different generations, and that require the corresponding attention of human resource managers and public policy-makers.

\section{Summary, proposals for policy, extensions, and limitations of this study}

From the data provided by the 2006-2010 ECVT, we selected two generations of workers and identified some of the factors, personal and work-related, that differentiate those generations. The results indicate that generational differences between the Boomers and the Gen-Xers do exist. Basically, the Boomers identify more with their work and the company, while the Gen-Xers are individuals for whom commitment to their work and company is lower. This attitude may be due to characteristics of life or biography, but we consider that there are certain forces that encourage this disinterest of the Gen-Xers, forces nurtured by the business environment and by work itself.

We believe that generating more interest among workers in knowing the objectives of the company, or to gain more satisfaction, can help improve the operations of the company. Consequently, it is advisable for companies 
to make commitments to guarantee a greater knowledge of internal aspects, which will boost efficiency. It would be desirable for companies to design policies to promote the identification of the worker with their objectives and competitive positions. These practices are already part of the literature on human resource management, but this literature does not currently take generational differences into account.

Public policies should reflect on the influence of labor deregulation on this attitude of a certain disinterest among the Gen-Xers towards work in general, and towards their employers. We believe that labor regulation, or some type of labor protection, can help to stimulate more positive attitudes towards work and the company, which may not be present at the moment on the part of the Gen-Xers.

One possible extension of this research is to verify whether this lower commitment to work, which, paradoxically, is not manifested in lower JS for the Gen-Xers, results in lower results for the company. Given that our study has a significant information base, some additional quantitative verification and qualitative analysis should be carried out to shed more light on these issues. That is, we should persist, along with other procedures, in estimating the impact of generational aspects on efficiency and productivity at work, and on the productive operations of the company in general.

Regarding the limitations of the study, there are times when more than two generations are present in the workplace. Our data do not allow us to extend to the analysis, which is undoubtedly important, of a third generation, such as the Millennials (see Pritchard and Whiting, 2015). Cogin (2011) distinguishes between four possible generations: Traditional, Baby Boomers, Generation X, and Generation Y; while Sibarani et al. (2015) consider three generations.

Perhaps studying how the three possible current generations interact, and how they behave in the workplace and in their attitudes toward the company, would allow us to establish more different patterns of behavior, which would serve to demonstrate the need to establish human resource and labor policies that respect the reality and the diversity of the generational factor. Given that the ECVT has not been compiled since 2010, an extension of this study could be made to incorporate three or four possible generations using the European Quality of Life Survey, although the information it provides is inferior - which is why we decided to use the ECVT at the outset.

\section{References}

Alonso, L.E. (2007). La crisis de la ciudadanía laboral. Anthropos Editorial. Barcelona.

Alwin, D. (1990). "Cohort Replacement and Changes in Parental Socialization Value", Journal of Marriage and Family, 52, May, 347-360. https://doi.org/10.2307/353031

Alwin, D., \& Krosnick, J. (1991). "Aging, Cohorts, and the Stability of Sociopolitical Over the Life Span", The American Journal of Sociology, 97, 1, 169-195. https://doi.org/10.1086/229744

Appelbaum, S., Serena, M., and Shapiro, B. (2005). "Generation "X" and the Boomers: An Analysis of Realities and Myths", Management Research News, 28, 1, 1-33. https://doi. org/10.1108/01409170510784751

Arsenault, P.M. (2004). 'Validating Generational Differences: A Legitimate Diversity and Leadership Issue,' The Leadership and Organization Development Journal, 25, 124-141. https://doi. org/10.1108/01437730410521813

Benson, J. \& Brown, M. (2011). "Generations at work: are there differences and do they matter?", The International Journal of Human Resource Management, 22: 9, 1843-1865. https://doi.org /10.1080/09585192.2011.573966

Brown, M. (2012). "Responses to work intensification: does generation matter?", The International Journal of Human Resource Management, 23: 17, 3578-3595. https://doi.or g/10.1080/09585192.2011.654348

Burke, M.E. (2005), SHRM Generational Differences Survey Report: A Study by the Society 
for Human Resource Management, Alexandria, VA: Society for Human Resource Management.

Clark, A.E. \& A.J. Oswald (1996). "Satisfaction and comparison income", Journal of Public Economics 61, pp. 359-381. https://doi. org/10.1016/0047-2727(95)01564-7

Clark, A.E. (1997). "Job satisfaction and gender: Why are women so happy at work?", Labour Economics 4, 341-372. https://doi.org/10.1016/ S0927-5371(97)00010-9

Cogin, J. (2011). “Are generational differences in work values fact or fiction? Multi-country evidence and implications", The International Journal of Human Resource Management, 23:11, 22682294 DOI: 10.1080/09585192.2011.610967

Daboval, J. (1998). “A Comparison Between Baby Boomers and Generation X Employees' Bases and Foci of Commitment", doctoral dissertation, Nova South Eastern University, Fort Lauderdale, FL. (Cited in Benson \& Brown (2011))

Eckman, E. (2004). "Similarities and Differences in Role Conflict, Role Commitment and Job Satisfaction for Female and Male High School Principals", Educational Administration Quarterly, 40, 3, 366-387. https://doi. org/10.1177/0013161X03257835

Gamero, C. (2004). Satisfacción laboral de los asalariados en España. Especial referencia a las diferencias por género. Cuadernos de Economía 27, pp. 109-146.

Gamero, C. (2005). La satisfacción laboral en España: un enfoque socioeconómico. CES. Madrid.

Gamero, C. (2010). Satisfacción laboral de los asalariados inmigrantes. Revista de Economía Aplicada 54, Vol XVIII, pp. 33-56.

Gamero, C. (2010). Satisfacción laboral y tipo de contrato en España. Investigaciones económicas.vol. XXXI (3), 2007, 415-444
Gans, D., \& Silverstein, M. (2006). "Norms of Filial Responsibility for Aging Parents Across Time and Generations", Journal of Marriage and Family, 68, November, 961-976. https://doi. org/10.1111/j.1741-3737.2006.00307.x

Giancola, F. (2006). “The Generation Gap: More Myth than Reality”, Human Resource Planning, 29, 4, 32-37.

Giménez-Nadal, J.I., Molina, J.A. \& Ortega, R. (2012). "Self-employed mothers and the workfamily conflict", Applied Economics, Vol. 44, pp. 2133-2148. https://doi.org/10.1080/00036846 .2011 .558486

Groot, W. \& Massen, H. (1999). "Job satisfaction of older workers", International Journal of Manpower, 20, p. 343-360. https://doi. org/10.1108/01437729910289701

Homer, P.M. \& Kahle, L.R. (1988). “A Structural Equation Test of the Value-AttitudeBehavior Hierarchy", Journal of Personality Social Psychology, 54, 638-646. https://doi. org/10.1037/0022-3514.54.4.638

Hui-Chun Yu, \& Miller, P. (2005). "Leadership style: The X Generation and Baby Boomers compared in different cultural contexts", Leadership \& Organization Development Journal, Vol. 26 Iss: 1 pp. 35 - 50. https://doi. org/10.1108/01437730510575570

Iverson, R., \& Buttigieg, D. (1999). "Affective, Normative and Continuance Commitment: Can the 'Right Kind' of Commitment be Managed?", Journal of Management Studies, 36, 3, 307-333. https://doi.org/10.1111/1467-6486.00138

Jorgensen, B. (2003). "Baby Boomers, Generation X and Generation Y: Policy Implications for Defence Forces in the Modern Era”, Foresight, 5, 4, 41-49. https://doi.org/10.1108/14636680310494753

Jurkiewicz, C. (2000). "Generation X and the Public Employee", Public Personnel Management, 29, 1, 55-74. https://doi. org/10.1177/009102600002900105 
Lasierra, José Manuel (2012). "Determinants of work organization in the modern firm: change and continuity in the Spanish labour relations", Int. J. of Human Resource Management 23:1-2 January 71-91

Lasierra, Jose Manuel, Jose Alberto Molina \& Raquel Ortega (2015). Generational Differences at Work in Spain, Munich Personal RePEc Archive, http://mpra.ub.uni-muenchen.de/64768/

Lin Dongyu, Dean P. Foster \& Lyle H. Ungar (2011). VIF-Regression: A Fast Regression Algorithm for Large, Journal of the American Statistical Association, Vol. 106, No. 493: $232-$ 247. https://doi.org/10.1198/jasa.2011.tm10113

Lydon, R. \& Chevalier, R. (2002). "Estimates of the effect of wages on job satisfaction", CEP-LSE Discussion Papers, 0531

Lyons, S. \& Kuron, L. (2014). "Generational differences in the workplace: a review of the evidence and directions for future research", Journal of Organizational Behavior, Vol. 35, pp. S139-S157. https://doi.org/10.1002/job.1913

McMullin, J., Comeau, T., Jovic, W. (2007). "Generational Affinities and Discourses of Difference: A Case Study of Highly Skilled Information Technology Workers", British Journal of Sociology, 58, 2, 297-316. https://doi. org/10.1111/j.1468-4446.2007.00152.x

Molina, J.A. (2015), "Caring within the family: reconciling work and family life", Journal of Family and Economic Issues, Vol. 36, pp. 1-4. https://doi.org/10.1007/s10834-015-9441-8

Pritchard, K. \& Whiting, R. (2015). "Generational Diversity at Work: New Research Perspectives", Personnel Review, Vol. 44 Iss: 1, pp.176 - 179

Rico Belda, Paz (2012). Satisfacción laboral de los asalariados en España. Revista de Métodos Cuantitativos para la Economía y la Empresa, vol. 14, diciembre, 2012, pp. 137- 158

Roberts, J., \& Manolis, C. (2000). "Baby Boomers and Busters: An Exploratory Investigation of Attitudes towards Marketing, Advertising and Consumerism", Journal of Consumer Marketing, 17, 6, 481-499. https://doi. org/10.1108/07363760010349911

Schuman, H., \& Scott, J. (1989). "Generations and Collective Memories", American Sociological Review, 54, 3, 359-381. https:// doi.org/10.2307/2095611

Shu, S.Y. (1998). "The influence of managers' leadership styles on job satisfaction and organizational commitment of different generation cohorts", citado en Hui-Chun \& Miller, (2005).

R. M. Sibarani, J. H. Tjakraatmadja, U. S. Putro, N. S. Munir (2015) “The Influence of Multigenerational Workforce in Effective Informal Team Learning", Journal of Economics and Business Research, Volume XXI, No. 2, pp. 199-217

Sirias, D., Karp, H.B., Brotherton, T. (2007). Comparing the levels of individualism and collectivism between boomers and generation $\mathrm{X}$ : Implications for teamwork. Management Research news, Vol. 30, Issue: 10, pp. 849-861.

Sloane, P. \& Williams, H. (2000). "Job satisfaction, comparison earnings and gender", Labour, 14, p. 473-501. https://doi.org/10.1111/14679914.00142

Smith, T. (2007). "Job Satisfaction in the United States", Working Paper, National Opinion Research Centre, University of Chicago, April 17.

Smola, K. W. \& Sutton, Ch. D. (2002). "Generational differences: revisiting generational work values for the new millennium", Journal of Organizational Behavior 23, 363-382 Vol. 23, No. 11, 2268-2294.

Solow, R. (1992): El mercado de trabajo como institución social. Alianza Editorial, Madrid.

Standing, G. (2013). El precariado. Una nueva clase social. Barcelona: Pasado y Presente.

Wallace, J. (2006). "Work Commitment in the Legal Profession: A Study of Baby Boomers 
and Generation Xers", International Journal of the Legal Profession, 13, 2, 137-151. https://doi. org/10.1080/09695950600961293

Yankelovich Inc. (2000). Generational Marketing, Harperbusiness, New York, NY.

\section{Authors:}

1. Jose Manuel Lasierra, Dr. in Economics, Full Professor, Applied Economics, University of Zaragoza, Spain. E-mail: jmlasie@unizar.es

ORCID

(D) 0000-0002-4277-3760

\section{Contribution of each author}

\begin{tabular}{lc}
\hline Contribution & Jose Lasierra \\
\hline 1. Definition of the research problem & $\sqrt{ }$ \\
2. Development of hypotheses or research questions (empirical works) & $\sqrt{ }$ \\
3. Development of theoretical propositions (theoretical essays) & $\sqrt{ }$ \\
4. Theoretical reasoning / Literature review & $\sqrt{ }$ \\
5. Definition of methodological procedures & $\sqrt{ }$ \\
6. Data collection & $\sqrt{ }$ \\
7. Statistical analysis & $\sqrt{ }$ \\
8. Analysis and interpretation of data & $\sqrt{ }$ \\
9. Critical revision of the manuscript & $\sqrt{ }$ \\
10. Writing of the manuscript & $\sqrt{ }$ \\
11. Other (please specify) & \\
\hline
\end{tabular}

\section{Erratum}

Where was written:

"Review of Business Management, São Paulo, v.21, n.5, p.953-969, oct/dec. 2019.”

Now read:

"Rev. Bras. Gest. Neg. São Paulo v.21 n.4 oct-dec. 2019 p. 953-969” 